\title{
Strategy for improving learning quality assessed from teachers performance in senior high
}

\author{
Malda Redy ${ }^{1}$, Edi Harapan ${ }^{2}$, Rohana Rohana ${ }^{2}$ \\ ${ }^{1}$ Sekolah Menengah Atas Negeri 3 Sekayu, Indonesia \\ ${ }^{2}$ Universitas PGRI Palembang, Indonesia
}

\begin{tabular}{l} 
Article Info \\
\hline Article history: \\
Received Jul $9^{\text {th }}, 2021$ \\
Revised Aug $14^{\text {th }}, 2021$ \\
Accepted Aug $30^{\mathrm{h}}, 2021$ \\
\hline
\end{tabular}

\section{Keyword:}

Learning quality

Teachers performanc

\begin{abstract}
This study aims to identify and describe strategies for improving the quality of learning in terms of teacher performance at the State Senior High School 3 of Sekayu, the obstacles faced and the results achieved. The research data collection techniques: 1) interview, 2) observation, 3) documentation. The research data analysis technique refers to qualitative research using 3 stages: 1) the processing data, 2) the reducing data, 3) the analyzing data. The results of this study: (1) the teachers creates innovative, effective, and fun learned by using infocus and utilizing hotspot facilities. In delivering learning materials, teachers use digital literacy as a supporting means to align the learning material delivered; (2) Constraints faced by potential, intelligence, and interest in accordance with the level of development and ability of students have not been achieved than expected, where the potential, intelligence and interest of students at the State Senior High School 3 of Sekayu are different; (3) The results achieved from strategies in improving the quality of learning in terms of teacher performance at the State Senior High School 3 of Sekayu, the fulfillment of the implementation of the delivered learning, where the learning process is innovative, active, and fun in accordance with the objectives of curriculum development in 2013 which is designed which is divided into 2 ( two), namely the implementation of learned which refers to the work program for a year (prota) and the implementation of learned which refers to the work program during the semester (prosem).
\end{abstract}

(C) 2021 The Authors. Published by IICET.

This is an open access article under the CC BY-NC-SA license

(https://creativecommons.org/licenses/by-nc-sa/4.0

\section{Corresponding Author:}

Redy, M.,

Sekolah Menengah Atas Negeri 3 Sekayu, Indonesia

Email: redymalda@gmail.com

\section{Introduction}

Education in schools must be developed according to community needs. Education in schools must be managed properly in order to develop quality human resources. Management and development of education is related to school management [1]. [2] Explains that the achievement of educational goals that have been set jointly by school members, requires effective, conducive and harmonious school conditions between education personnel in schools, including principals, teachers, administrative staff, and parents of students / the community. each of which has a fairly large role in achieving organizational goals [2]. Principals who are successful when they understand the existence of the school as a complex and unique organization, and are able to carry out the role of the principal as a supervisor who is given the responsibility to lead the school. 
School is one of the factors that determine student learning outcomes. The higher the student's learning ability and the quality of teaching in schools, the higher the student learning outcomes [3]. Education in general aims to develop student potential. As a good teacher, it is natural that he wants as many of his students as possible to pass or get good grades. [4] that the teacher is a very decisive component in the implementation of a learning strategy. Based on this opinion, it can be emphasized that one of the external factors that greatly affects student learning outcomes is the teacher. The teacher is one of the most important elements in education. The quality of education is very much determined by the quality standards of teachers. Therefore, teachers need to improve their competence as stated in Law Number 14 of 2005 concerning Teachers and Lecturers.

[4] That the teacher is a very decisive component in the implementation of a learning strategy. One of the external factors that greatly affects student learning outcomes is the teacher. The teacher in the learning process plays a very important role, especially for students at elementary school age, it cannot be replaced by other devices such as television, radio, and computers. Because students are developing organisms that need adult guidance and help. The performance of teachers in teaching is an important aspect in efforts to improve the quality of life of the nation. This is because the source of teachers is the main force for all efforts to educate and learn the nation's children. This ability does not just exist, but is obtained from a long process of education and learning. With this process, we can get competent figures in their fields and then this changes the conditions of a general problem [5].

The various teacher performance development programs mainly aim to improve the abilities and skills of teachers in planning, developing, implementing and supervising the learning process to support improving the quality of education in each school unit [6].Teaching problems are efforts to assist students in achieving specific teaching goals directly, for example making lesson units, presenting information, asking questions, evaluating. Meanwhile, management issues are efforts to create and maintain conditions in such a way that the teaching and learning process can take place effectively and efficiently, for example providing reinforcement, developing teacher-student relationships, making productive group rules [7]. [8] Suggests that teacher performance is carrying out the learning process both in the classroom and outside the classroom in addition to doing other activities, such as working on school administration and learning administration, implementing guidance and services to students, and implementing appraisal.

[9] "The Effect of Teacher Professionalism and Principal Supervision on Teacher Performance". The results of this study concluded that: 1) There is an effect of teacher professionalism on the performance of teachers at SMP Negeri Sub Rayon 16, Sukarami District, Palembang City. 2) There is an effect of Principal Supervision on Teacher Performance at SMP Negeri 16 Sub District Sukarami, Palembang City. 3). There is an Influence of Teacher Professionalism and Principal Supervision on the Teacher Performance of Sub District 16 Junior High School Teachers in Sukarami District, Palembang City. In this study, the researcher concludes that there are similarities and differences made by previous researchers with current research, namely both studying the principal. Whereas the difference between previous research and current research is that it lies in the object used as the source of research data and the place of research.

\section{Method}

In this research is a qualitative descriptive research method. This research design refers to a qualitative method with a descriptive approach. [10] the research method is the method used by researchers in collecting research data. Furthermore, [11] states that a method is defined as a method used to achieve predetermined goals. In this research is a qualitative descriptive research method. [12], the descriptive method is a method used to examine the status of a group of people, an object, a set of conditions, a system of thought, or a class of events in the present. Qualitative methods [13] define qualitative methods as research procedures that produce descriptive data in the form of written or spoken words from people and observed behavior. The resulting data are in the form of words, pictures and human behavior. [13] adds his opinion that research that has qualitative research is research that is conducted by observing, and is carried out in a natural setting or overall context, and the main data collection tool is research itself. Furthermore, Sudaryono (2009: 9) suggests that the research method is the way to achieve goals.

\section{Results and Discussions}

The results of this study explain strategies for improving the quality of learning in terms of teacher performance in SMA Negeri 3 Sekayu, the obstacles faced by teachers in implementing strategies for improving the quality of 
learning at SMA Negeri 3 Sekayu and the results achieved from strategies in improving the quality of learning in terms of teacher performance in SMA Negeri 3 Sekayu.

Besides that, the results of this study are also supported by data collected based on research results such as the results of interviews with school principals, interviews with teachers, and interviews with representatives of the curriculum field. Furthermore, the research data is based on observation and documentation data as supporting data to complement the research results.

The learning process at SMA Negeri 3 Sekayu is assisted by a total of 35 teachers consisting of 29 civil servant teachers plus 16 honorarium teachers. Furthermore, from the results of the administrative personnel information from the 29 civil servant teachers who already had teaching certificates, 19 were PNS teachers (65.52\%), while 10 teachers (34.48\%) did not have educator certificates. Besides that, there are still some civil servant teachers who are not linear from their disciplines in delivering learning materials.

Strategies for improving the quality of learning carried out by teachers at SMA Negeri 3 Sekayu include the following. (1) Creating innovative, effective, and fun learning. To create innovative learning, teachers make use of existing facilities in schools as a means of learning resources, especially using infocus and utilization of hotspots. The teacher in creating effective and fun learning, where the learning process that is delivered refers to the set time allocation and summarizes the learning material that is delivered in outline with the help of existing learning resource media facilities; (2) Teachers in improving the quality of learning carried out at SMA Negeri 3 Sekayu in delivering learning materials make use of digital literacy as a supporting means to harmonize the learning material presented; (3) Strategies for improving the quality of learning carried out by teachers at SMA Negeri 3 Sekayu, armed with activities obtained through education and training, MGMP, seminars and other activities that add insight, teachers apply strategies in teaching according to the insights gained.

The findings of the research on strategies for improving the quality of learning in terms of teacher performance at SMA Negeri 3 Sekayu are as follows. (1) Creating innovative, effective, and fun learning. To create innovative learning, teachers make use of existing facilities in schools as a means of learning resources, especially using infocus and utilization of hotspots. (2) Delivering learning materials utilizing digital literacy as a supporting means to harmonize the learning material delivered. (3) Armed with activities obtained through education and training, MGMP, seminars and other activities that add insight, the teacher applies strategies in teaching according to the insights obtained.

Some of the obstacles faced by teachers in implementing strategies for improving the quality of learning at SMA Negeri 3 Sekayu are as follows. (1) The increase in potential, intelligence, and interest in accordance with the level of development and ability of students has not been achieved than expected, where the potential, intelligence and interest of students at SMA Negeri 3 Sekayu are different. This is based on the research findings that the majority of students accommodated at SMA Negeri 3 Sekayu are from local villages and from several other villages that are not more than $15 \mathrm{Km}$ away. This is reflected in the academic and non-academic achievements of students at SMA Negeri 3 Sekayu which are still below other SMAs in Sekayu, both in the academic achievements of the National Examination Value achieved and achievements in non-academic fields. (2) The facilities and infrastructure in terms of learning resources (learning media) in SMA Negeri 3 Sekayu are still classified as insufficient, where there are 4 learning sources (learning media) such as Infocus. There should be 12 appropriate Infocus for learning activities. (3) Lack of existing equipment in the laboratory to meet existing needs, such as equipment in the Physics Laboratory, Chemistry Laboratory, Biology Laboratory

The results achieved from strategies in improving the quality of learning in terms of teacher performance at SMA Negeri 3 Sekayu are described as follows: (1) The fulfillment of the implementation of the learning delivered, where the learning process is innovative, active, and fun in accordance with the objectives of curriculum development in 2013 designed which is divided into 2 (two), namely the implementation of learning which refers to the work program for a year (prota) and the implementation of learning which refers to the work program during the semester (prosem); (2) The achievement of students in completing the reading of $10 \mathrm{Juzz}$ Al Qur'an and $20 \mathrm{Juzz}$ Al Qur'an. Achieved 100\% student graduation rate, achieved the expected accreditation, namely obtaining "A" accreditation with an achievement value of 91, achieving the SMA Negeri 3 Sekayu program in the title Adiwiyata school, achieving implementation of the model school program.

In line with research conducted [4] that teachers are a very decisive component in the implementation of a learning strategy. One of the external factors that greatly affects student learning outcomes is the teacher. The teacher in the learning process plays a very important role, especially for students at elementary school age, it cannot be replaced by other devices such as television, radio, and computers. Because students are developing organisms that need adult guidance and help. 
This research is supported by the results of research conducted [9] "The Effect of Teacher Professionalism and Principal Supervision on Teacher Performance". The results of this study concluded that: 1) There is an effect of teacher professionalism on the performance of teachers at SMP Negeri Sub Rayon 16, Sukarami District, Palembang City. 2) There is an effect of Principal Supervision on Teacher Performance at SMP Negeri 16 Sub District Sukarami, Palembang City. 3). There is an Influence of Teacher Professionalism and Principal Supervision on the Teacher Performance of Sub District 16 Junior High School Teachers in Sukarami District, Palembang City. In this study, the researcher concludes that there are similarities and differences made by previous researchers with current research, namely both studying the principal. Whereas the difference between previous research and current research is that it lies in the object used as the source of research data and the place of research.

[13] through their journal entitled "The Effect of Academic Supervision and Teacher Professional Competence on Teacher Performance in Public High Schools in Tanjung Raja District". The conclusions of this study are: Based on the results of research and discussion that has been carried out before both through descriptive statistical analysis and inferential statistical analysis, and the findings in this study it can be concluded that first, there is a significant effect of academic supervision on the performance of State Senior High School teachers. in Tanjung Raja District. Second, there is a significant influence on the professional competence of teachers on the performance of teachers in Public Senior High Schools in Tanjung Raja District. Third, there is a significant effect of academic supervision and professional competence of teachers together on the performance of teachers of public high schools in Tanjung Raja District. In this study, the researcher concludes that there are similarities and differences made by previous researchers with current research, namely both examining teacher performance. Whereas the difference between previous research and current research is that it lies in the object used as the research data source and the place of research.

One of the factors that affect teacher performance is the principal. As supervisors, the principal is expected to be able to act as a consultant, as a facilitator who understands the needs of teachers and is able to provide alternative solutions. In addition, the principal is also expected to motivate teachers to be more creative and innovative and maximize performance. Apart from the teacher factor, the role of the principal is also important considering that currently the quality of education in Indonesia is not evenly distributed between regions.

Research [14] through their journal entitled "The Effect of Academic Supervision and Teacher Professional Competence on Teacher Performance in Public High Schools in Tanjung Raja District". The conclusions of this study are: Based on the results of research and discussion that has been carried out before both through descriptive statistical analysis and inferential statistical analysis, and the findings in this study it can be concluded that first, there is a significant effect of academic supervision on the performance of State Senior High School teachers. in Tanjung Raja District. Second, there is a significant influence on the professional competence of teachers on the performance of teachers in Public Senior High Schools in Tanjung Raja District. Third, there is a significant effect of academic supervision and professional competence of teachers together on the performance of teachers of public high schools in Tanjung Raja District. In this study, the researcher concludes that there are similarities and differences made by previous researchers with current research, namely both examining teacher performance. Whereas the difference between previous research and current research is that it lies in the object used as the research data source and the place of research.

[15] "The Effect of Work Motivation and Work Environment on the Performance of Muhammadiyah High School Teachers in Kebumen Regency." This study concludes that work motivation has a significant effect on the performance of Muhammadiyah high school teachers in Kebumen Regency, because the significance value of $t$ is 0.000 smaller than $\alpha=0.05(0.000<0.05)$ with a regression coefficient of 0.699 . The work environment has a significant effect on the performance of Muhammadiyah high school teachers in Kebumen Regency, because the significance value of $t$ is 0.014 which is smaller than $\alpha=0.05(0.014<0.05)$ with a regression coefficient of 0.248 . Work motivation and work environment together have a significant effect on the performance of SMA Muhammadiyah teachers in Kebumen Regency, because the significance value of $F$ is 0.000 less than $\alpha=0.05(0.000<0.05)$ and is able to contribute to the teacher performance variable 0.726 . or $72.6 \%$, while the remaining $27.4 \%$ is influenced by other variables not examined in this study. In this study, the researcher concludes that there are similarities and differences made by previous researchers with current research, namely both examining teacher performance. Whereas the difference between previous research and current research is that it lies in the object used as the research data source and the place of research.

\section{Conclusions}


Based on the results of the research, the strategy to improve the quality of learning in terms of teacher performance at SMA Negeri 3 Sekayu creates innovative, effective, and fun learning, the fulfillment of the implementation of the delivered learning, where the learning process is innovative, active, and fun in accordance with the objectives of curriculum development in 2013 which is designed divided into 2 (two), namely the implementation of learning which refers to the work program for a year (prota) and the implementation of learning which refers to the work program during the semester (prosem).

\section{References}

Arikunto, Suharsimi, 2010. Prosedur Penelitian Suatu Pendekatan Praktek. Edisi Revisi. Jakarta: Rineka Cipta. Aqib, Zainal. 2014. Mutu Pendidikan. Jakarta: Dian Pustaka.

Djamarah, Syaeful Bahri dan Aswan Zain. 2012. Strategi Belajar Mengajar. Jakarta: Rineka Cipta.

Djamarah, S. B. 2010. Metode dan Statistika Penelitian. Jakarta: Rajawali Pers.

Eliyanto. 2018. Pengaruh Motivasi Kerja dan Lingkungan Kerja Terhadap Kinerja Guru SMA Muhammadiyah di Kabupaten Kebumen. Jurnal Manajemen dan Administrasi Pendidikan. Volume 3 Nomor 3, Juni 2018. Halaman 322-335.

Hapizoh, Edi Harapan, Destiniar, 2020. Pengaruh Profesionalisme Guru dan Supervisi Kepala Sekolah Terhadap Kinerja Guru. Jurnal Manajemen, Kepemimpinan, dan Supervisi Pendidikan. Volume 5 Nomor 2, Juli 2020. Halaman 168-174.

Moleong, Lexy. 2011. Metodologi Penelitian Kualitatif. Bandung: Remaja Rosdakarya.

Mardalena, Yasir Arafat, Happy Fitria. 2020. Pengaruh Supervisi Akademik dan Kompetensi Profesional Guru Terhadap Kinerja di Sekolah Menengah Atas Negeri di Kecamatan Tanjung Raja. Jurnal Intelektualita: Keislaman, Sosial, dan Sains. Volume 9 Nomor 1, Juni 2020. Halaman: 103-114.

Ngalim. Purwanto. 2015. Administrasi dan Supervisi Pendidikan. Jakarta: Rineka Cipta.

Prastowo, A. 2011. Penelitian Kualitatif: Teknik Mendesain Pembelajaran. Jogjakarta: Diva Press.

Rusyan. 2016. Manajemen Peningkatan Kinerja Guru. Konsep Strategi dan Implementasi. Bandung: Remaja Rosdakarya.

Sumardin. 2016. Pengembangan Profesionalisme Guru Berbasis MGMP Model dan Implementasinya. Yogyakarta: Budi Utama.

Susanto, Ahmad. 2016. Teori Belajar dan Pembelajaran di sekolah Dasar. Jakarta: Prenadamedia Group.

Usman, Moch, Uzer. 2012. Menjadi Guru Profesional. Bandung: Remaja Rosdakarya.

Wasliman, Iim. 2012. Problemantika Pendidikan Dasar dan Menengah. Bandung: Universitas Pendidikan Indonesia. 